\title{
FAKTOR YANG BERHUBUNGAN DENGAN PERILAKU SEKSUAL PADA REMAJA
}

\author{
Novi Wulan Sari, S.ST, M.Kes \\ Universitas Fort De Kock, Bukittinggi \\ email: noviwulansari27@gamil.com
}

\section{Submitted : 25-06-2020, Reviewer:27-06-2020, Accepted: 30-06-2020}

\begin{abstract}
ABSTRAK
Data Depkes RI tahun 2014, ditemukan remaja SMP yang melakukan hubungan seks sebesar 5,3\% dan SMA 10,3\%. Data KPAI Sumatera Barat, ditemukan 17 kasus perilaku seksual pranikah pada remaja 10 orang diantaranya adalah siswa SMA. Penelitian ini bertujuan untuk mengetahui faktor-faktor yang berhubungan dengan perilaku seksual pada remaja di SMK Negeri 2 Bukittinggi. Jenis penelitian yang digunakan adalah deskriptif analitik dengan desain cross sectional study. Populasi seluruh remaja kelas $\mathrm{X}$ dan XI berjumlah 989 orang dengan teknik pengambilan sampel simple random sampling yang berjumlah 91 orang. Hasil analisis univariat didapatkan 16,5\% remaja memiliki perilaku seksual yang beresiko. Sebesar 51,6\% remaja terpapar terhadap media massa tentang perilaku seksual. Sebesar 13,2\% pola asuh orang tua termasuk kedalam pola asuh permisif dan 33,0\% termasuk kedalam pola asuh otoriter. Sebesar 56,0\% teman sebaya mendukung tentang perilaku seksual. Hasil uji statistik didapatkan terdapat hubungan media massa $(\mathrm{p}=0,007$ dan OR 8), pola asuh orang tua $(\mathrm{p}=0,006)$ dan dukungan teman sebaya $(p=0,026$ dan OR 4$)$ dengan perilaku seksual pada remaja. Disimpulkan bahwa ada hubungan media massa, pola asuh orang tua dan dukungan teman sebaya dengan perilaku seksual pada remaja.
\end{abstract}

Kata Kunci : Media Massa, Pola Asuh Orang Tua, Dukungan Teman Sebaya, Perilaku Seksual

\begin{abstract}
Republic of Indonesia Ministry of Health data in 2014 found junior high school teenagers who had sex by $5.3 \%$ and high school 10.3\%. West Sumatra KPAI data, found 17 cases of premarital sexual behavior in teenagers 10 of whom are high school students. This study aims to determine the factors associated with sexual behavior in adolescents at SMK Negeri 2 Bukittinggi. This type of research is analytic descriptive with cross sectional study design. The population of all class X and XI teenagers is 989 people with a simple random sampling technique, amounting to 91 people. Univariate analysis results found 16,5\% of adolescents have risky sexual behavior. 51,6\% of adolescents are exposed to mass media about sexual behavior. As many as 13,2\% of parenting patterns are included in permissive parenting and 33,0\% are included in authoritarian parenting. 56,0\% of peers support about sexual behavior. The results of statistical tests found there is a relationship of mass media ( $p=0,007$ and $O R 8)$, parenting $(p=0,006)$ and peer support ( $p=0,026$ and OR 4) with sexual behavior in adolescents. It was concluded that there was a relationship of mass media, parenting parents and peer support with sexual behavior in adolescents.
\end{abstract}

Keywords : Mass Media, Parenting Parents, Peer Support, Sexual Behavior 


\section{PENDAHULUAN}

Remaja merupakan individu baik perempuan maupun laki-laki yang berada pada masa atau usia antara anak-anak dan dewasa. Menurut klasifikasi World Health Organization (WHO) batasan remaja usia 10 - 19 tahun. Menurut peraturan menterikesehatan RI Nomor 25 tahun 2014. Remaja adalah penduduk dalam rentang usia 10-18 tahun dan menurutbadan kependudukan dan keluarga berencana (BKKBN) rentang usia remaja adalah 10-24 tahun dan belum menikah (WHO, 2014).

Anak-anak dan remaja sebaiknya tidak hanya diberikan pemahaman seks dari sisi biologi saja, tetapi juga dari segi politik, ekonomi, sosial dan budaya. Pekerja seks komersil misalnya keberadaan mereka jangan semata-mata dianggap sebagai sampah masyarakat. Perlu ada pemahaman bahwa banyaknya PSK (Pekerja Seks Komersil) disebabkan oleh faktor ekonomi, sehingga mereka tidak lagi bertanggung jawab terhadap organ reproduksi dan tidak menyadari akan terjadinya penularan virus HIV dan penyakit lainnya. Berbeda dengan remaja putri lainnya yang memiliki tanggung jawab penuh terhadap organ reproduksinya sendiri sebagai proteksi dari hal-hal yang tidak diinginkan (Andika, 2010).

Data survey Departemen Kesehatan Revublik Indonesia (Depkes RI) tahun 2014 yang dilakukan di 18 Provinsi dengan mengambil 38 Kabupaten di 72 SMP dan 72 SMA didapatkan hasil yang melakukan hubungan seks SMP 5,3\% dan SMA 10,3\%. Penelitian dilakukan di 4 kota besar seperti Medan, Jakarta Pusat, Bandung dan Surabaya berdasarkan data Depkes RI tahun 2009 menunjukkan 35,95\% remaja mempunyai teman sudah melakukan hubungan seks dab

6,9\%responden telah melakukan hubungan seks (Depkes RI , 2018)

Pada awal tahun 2016 diketahui terdapat 3 orang remaja di Kota Padang diamankan polisi terkait prostitusi yang diantara nya telah melakukan hubungan seksual di waktu SMP. Berdasarkan informasi dari ketua komsi perlindungan anak (KPAI) bahwa dari tahun 2015Februari 2016 terdapat 17 kasus perilaku seksual pranikah pada remaja Sumatra Barat 10 diantaranya adalah siswa SMA. Sehingga siswa SMA yang merupakan remaja awal yang memerlukan perhatia khusus mengenai perilaku seksual (Kepolisian, 2018).

Hal ini terkait dengan beredarnya informasi yang salah dikalangan remaja mengenai pengetahuan seputar seks. Masih banyak yang beranggapan kehamilan tidak akan terjadi apabila hubungan seks dilakukan hanya sekali. Ada lagi yang percaya melompat-lompat atau jongkok 
sehabis melakukan hubungan seks membuat sperma yang masuk akan keluar lagi, sehingga tidak terjadi pembuahan yang akan mengakibatkan kehamilan (Nugraha, 2010).

Data dari Biro Pusat Statistik Kota Padang tahun 2018 ditemukan distribusi umur pertama kali melakukan hubungan seksual banyak ditemukan pada remaja usia 15 - 19 tahun yaitu 2,7\%. Ditemukan juga angka sebanyak $35 \%$ wanita menyatakan untuk menunjukkan rasa saling mencintai sebagai suatu alasan menyetujui hubungan seksual pranikah. (BPS Kota Padang, 2018).

Hasil penelitian Aniva dwi putri (2016) tentang Gambaran Tingat Pengetahuan Remaja Tentang

Penyimpangan Perilaku Seksual Di SMA Negeri 1 Bayang Tahun 2016 ditemukan hasil sebanyak 38 orang $(51,4 \%)$ mempunyai tingkat pengetahuan tinggi, sebanyak 59 orang $(79,7 \%)$ memiliki sikap positif tentang perilaku seksual pranikah. 59 orang $(79,7 \%)$ memiliki perilaku seksual pranikah tidak beresiko. Nilai $\mathrm{p}=0,001$ ( $\mathrm{p}$ $<0,05)$ ada hubungan yang bermakna antara tingkat pengetahuan dengan perilaku seksual pranikah remaja di SMA negeri 1 Bayang. Nilai $p=0,038(p<0,05)$ ada hubungan yang bermakna antara sikap dengan perilaku seksual remaja di SMA Negeri 1 Bayang.
Penelitian yang yan sama dilakukan oleh Musthalia, dkk (2016) dengan judul perilaku seksual remaja dilingkungan lokalisasi Kabupaten Sidoarjo, pada penelitian ini disimpulkan bahsa masih banyak terjadi kenakalan remaja dan menunjukakan adanya perilaku seksual di lingkungan lokalisasi Kabupaten Sidoarjo.

SMK Negeri 2 adalah SMK Negeri terfavorit di Kota Bukittinggi yang terletak di kawasan yang banyak memberikan media, informasi tentang pengetahuan. Dimana SMK Negeri 2 ini terletak berdekatan dengan kawasan Pasar Atas. SMK Negeri 2 mempunyai guru BK akan tetapi hanya berfungsi pada saat siswasiswi yang bermasalah, siswa-siswi SMK Negeri 2 yang mana mereka dengan bebasnya berkeliaran disekitarnya berpasangpasangan di waktu jam istirahat, maupun jam pelajaran dan pulang sekolah. SMK Negeri 2 juga berdekatan dengan Ramayana dan Jam Gadang Bukittinggi. Banyaknya yang mempengaruhi siswa terhadap perkembangan perilaku seksual seperti warnet, buku dan majalah, lingkungan, teman yang lebih besar di kawasan tersebut merupakan salah satu faktor penyebab.

Survey awal peneliti di SMK Negeri 2 Bukittinggi, dari hasil wawancara pada guru BK, mereka mengatakan sejak 4 tahun terakhir sebanyak 18 orang siswa siwi yang keluar dari sekolah, tetapi guru BK mengatakan bahwa tidak ada siswi yang 
hamil diluar nikah akan tetapi siswi yang keluar dari sekolah setelah beberapa bulan terlihat sudah mempunyai anak. Dan masalah prilaku seksual lainnya ditemukan siswi yang sedang berpacaran di kelas, menyebarkan video porno di grup kelas, menyimpan foto sedang berciuman dengan pacar nya di Handphone, membuat video sedang mandi tanpa busana untuk pacarnya. peneliti melakukan wawancara terhadap 10 orang siswa bahwa 8 orang siswa sudah pernah berciuman dengan pacarnya dan mereka tidak mengetahui efek samping terhadap hal tersebut, serta mereka mengatakan tidak pernah diperhatikan atau dinasehati tentang perilaku seksual oleh orang terdekat nya. Mereka mengatakan lebih terbuka pada temannya dari pada orang tuanya. Dan 2 orang siswa mengatakan tidak pernah melakukan ciuman atau perilaku seksual lainnya.

\section{METODE PENELITIAN}

Penelitian ini merupakan penelitian deskriptif analitik dengan desain cross sectional study yang dilakukan di SMK Negeri 2 Bukittinggi. Subjek penelitian adalah seluruh remaja kelas $\mathrm{X}$ dan $\mathrm{XI}$ berjumlah 989 orang dengan teknik pengambilan sampel simple $r$ andom sampling yang berjumlah 91 orang. Data dikumpulkan menggunakan kuesioner. Data dianalisis secara univariat dan bivariat dengan menggunakan uji statistik chisquare dengan derajat kepercayaan $\alpha=$ 0,05 .

\section{HASIL DAN PEMBAHASAN}

\section{Karakteristik Responden} Karakteristik Responden

\begin{tabular}{lcc}
\hline \multicolumn{1}{c}{ Karakteristik } & $\boldsymbol{f}$ & $\boldsymbol{\%}$ \\
\hline Umur : & & \\
12-16 tahun & 33 & 36,3 \\
17-25 tahun & 58 & 63,7 \\
\hline \multicolumn{1}{c}{ Jumlah } & $\mathbf{9 1}$ & $\mathbf{1 0 0}$ \\
\hline Jenis Kelamin : & & \\
Laki-Laki & 14 & 15,4 \\
Perempuan & 77 & 84,6 \\
\hline \multicolumn{1}{c}{ Jumlah } & $\mathbf{9 1}$ & $\mathbf{1 0 0}$ \\
\hline Tempat Tinggal : & & \\
Orang Tua & 70 & 76,9 \\
Kost & 18 & 19,8 \\
dll & 3 & 3,3
\end{tabular}

Pada tabel dapat dilihat bahwa dari 91 responden terdapat $58(63,7 \%)$ berumur antara 17-25 tahun yang termasuk kedalam kelompok remaja akhir. Sebesar 77 (84,6\%) berjenis kelamin perempuan dan sebesar 70 $(76,9 \%)$ tinggal bersama orang tua. 
2. Analisis Univariat

a. Perilaku Seksual Remaja

Distribusi Frekuensi Perilaku Seksual

Remaja

\begin{tabular}{lcc}
\hline $\begin{array}{c}\text { Perilaku Seksual } \\
\text { Remaja }\end{array}$ & $\boldsymbol{f}$ & $\boldsymbol{\%}$ \\
\hline Beresiko & 15 & 16,5 \\
Tidak Beresiko & 76 & 83,5 \\
\hline Jumlah & $\mathbf{9 1}$ & $\mathbf{1 0 0}$ \\
\hline
\end{tabular}

Tabel diatas dapat dilihat bahwa 15 $(16,5 \%)$ memiliki perilaku seksual yang beresiko.

Perilaku seksual di kalangan remaja saat ini sudah sangat mengkhawatirkan, sehingga berdampak pada persoalan kehamilan tidak diinginkan, aborsi dan kejadian HIV dan AIDS semakin tahun semakin meningkat. Hal ini juga dipengaruhi adanya pergeseran sikap yang lebih permisif pada hubungan seksual. Remaja Indonesia saat ini sedang mengalami perubahan sosial yang sangat cepat dari masyarakat tradisional menuju masyarakat modern, yang juga mengubah norma-norma, nilai-nilai dan gaya hidup mereka (Lutfianawati, 2014).

Hasil penelitian ini sejalan dengan penelitian yang dilakukan oleh Trisnawati (2010) tentang faktor-faktor yang berhubungan dengan perilaku seksual pada remaja SMA di Purwokerto, ditemukan
$12,8 \%$ remaja memiliki perilaku seksual beresiko. Namun, hasil penelitian ini berbeda dengan penelitian yang dilakukan oleh Pramita (2011) tentang hubungan komunikasi orang tua dan anak tentang seks dengan perilaku seks pada remaja di SMA N 1 Seyegan Sleman Yogyakarta, ditemukan $25 \%$ perilaku seks responden beresiko.

Adanya remaja yang memiliki perilaku seksual beresiko disebabkan oleh kurangnya pengetahuan tentang seks dan akibat dari perilaku seksual sehingga membuat remaja ingin mencobanya. Selain itu, juga disebabkan oleh meningkatnya libido seksual, rendahnya usia kematangan seksual yang diikuti oleh meningkatnya aktifitas seksual pada usiausia yang dini, perubahan-perubahan hormonal yang meningkatkan hasrat seksual remaja. Peningkatan hormon ini menyebabkan remaja membutuhkan penyaluran dalam bentuk tingkah laku tertentu. Penyaluran tersebut tidak dapat disalurkan karena adanya penundaan usia perkawinan. Perilaku seksual yang beresiko juga disebabkan oleh remaja yang tidak tinggal dengan orang tua, dimana $19,8 \%$ remaja kost dan 3,3\% tinggal dengan keluarga lain, sehingga kurangnya pengawasan orang tua pada remaja terutama dalam bergaul dengan lawan jenisnya.

b. Media Massa 
Distribusi Frekuensi Media Massa

\begin{tabular}{lll}
\hline \multicolumn{1}{c}{ Media Massa } & $\boldsymbol{f}$ & $\boldsymbol{\%}$ \\
\hline Terpapar & 47 & 51,6 \\
Kurang Terpapar & 44 & 48,4 \\
\hline Jumlah & $\mathbf{9 1}$ & $\mathbf{1 0 0}$ \\
\hline
\end{tabular}

Pada tabeldapat dilihat bahwa 47 $(51,6 \%)$ terpapar terhadap media massa tentang perilaku seksual.

Penyebaran informasi dan rangsangan melalui media massa yang dengan teknologi yang canggih (contoh: VCD, buku stensilan, foto, majalah, internet dan lain lain) menjadi tidak terbendung lagi. Remaja yang sedang dalam periode ingin tahu dan ingin mencoba, akan meniru apa dilihat atau didengar dari media massa, karena pada umumnya mereka belum pernah mengetahui masalah seksual secara lengkap dari orang tuanya (Sarwono, 2016).

Remaja telah menempatkan media massa sebagai sumber informasi seksual yang lebih penting dibandingkan orang tua. Paparan media massa, baik cetak (koran, majalah, buku-buku porno) maupun elektronik (TV, VCD, Internet), mempunyai pengaruh secara langsung maupun tidak langsung pada remaja untuk melakukan hubungan seksual (BKKBN, 2011).

Hasil penelitian ini sejalan dengan penelitian yang dilakukan oleh Andriani (2016) tentang hubungan pengetahuan, akses media informasi dan peran keluarga terhadap perilaku seksual pada siswa SMK Negeri 1 Kendari, ditemukan 92,2\% remaja mengakses media informasi. Penelitian yang dilakukan oleh Chaves et all (2007) di Amerika Serikat, menemukan bahwa media massa dapat mempengaruhi perilaku seksual pada remaja. Sebesar $40 \%$ perilaku seksual pada remaja dipengaruhi dari media internet.

Menurut peneliti, terpaparnya remaja terhadap media massa terlihat dari hasil analisa kuesioner yaitu $80,2 \%$ remaja terpapar terhadap televisi. Sebesar 92,3\% remaja terpapar terhadap internet, sebesar 96,7\% remaja terpapar terhadap handphone, dan sebesar $62,6 \%$ remaja terpapar terhadap video. Remaja yang terpapar terhadap media massa juga disebabkan oleh kemajuan dunia teknologi yang dapat mengakses berbagai macam informasi terutama tentang seksual akan mudah diperoleh oleh remaja, sehingga akan mengakibatkan dampak yang buruk pada remaja terhadap perilaku seksualnya.

c. Pola Asuh Orang Tua

Distribusi Frekuensi Pola Asuh Orang

Tua

\begin{tabular}{ccc}
\hline $\begin{array}{c}\text { Pola Asuh Orang } \\
\text { Tua }\end{array}$ & $f$ & $\%$ \\
\hline
\end{tabular}




\begin{tabular}{lcc}
\hline Permisif & 12 & 13,2 \\
Otoriter & 30 & 33,0 \\
Demokratis & 49 & 53,8 \\
\hline \multicolumn{1}{c}{ Jumlah } & $\mathbf{9 1}$ & $\mathbf{1 0 0}$ \\
\hline
\end{tabular}

Pada tabel dapat dilihat bahwa 12 $(13,2 \%)$ pola asuh orang tua termasuk kedalam pola asuh permisif dan $30(33,0 \%)$ termasuk kedalam pola asuh otoriter.

Pola asuh adalah proses pemeliharaan anak dengan menggunakan teknikdan metode yang menitikberatkan pada kasih sayang dan ketulusan cinta dari kedua orang tua. Pola asuh merupakan upaya yang persisten dan konsisten dalam menjaga dan membimbing anak dari mulai dilahirkan hingga remaja. Pola asuh dalam keluarga merupakan cara orangtua, yaitu ayah dan ibu dalam memberikan kasih sayang dalam mengasuh yang mempunyai pengaruh yang besar kepada anak untuk beradaptasi dengan dirinya dan lingkungannya. Bentuk pola asuh orangtua akan mempengaruhi pembentukan kepribadian anak setelah ia menjadi dewasa (Yusuf, 2011).

Hasil penelitian ini sejalan dengan penelitian yang dilakukan oleh Aguma (2014) tentang hubungan pola asuh orangtua terhadap perilaku seksual remaja di SMA Tri Bhakti Pekanbaru, ditemukan $18,1 \%$ pola asuh orang tua permisif dan $26 \%$ pola asuh orang tua otoriter. Hasil penelitian ini juga sejalan dengan penelitian yang dilakukan oleh Ungsianik (2016) tentang hubungan pola asuh orangtua dengan perilaku seksual berisiko pada remaja, khususnya remaja anak jalanan di Kota Depok. Hasil penelitian ditemukan $33,7 \%$ pola asuh orang tua otoriter.

Masih adanya pola asuh otoriter dan permisif yang didapatkan remaja, disebabkan oleh masih adanya remaja yang tidak tinggal dengan orang tua, sehingga membuat remaja lebih bebas untuk melakukan kegiatan apapun. Sedangkan remaja yang tinggal dengan orang tua juga ditemukan dengan pola asuh otoriter dan permisif yaitu sebesar $30,8 \%$. Hal ini akan membuat remaja tidak menuruti nasehat orang tuanya, dimana pada pola asuh permisif remaja lebih bebas untuk melakukan kegiatan apapun dan pada pola asuh otoriter remaja merasa terikat dengan aturan-aturan yang diterapkan oleh orang tua.

Hubungan orang tua dengan remaja yang tidak baik juga dapat disebabkan oleh orang tua yang sibuk dengan pekerjaannya, mereka tidak terlalu memperhatikan apa yang sedang dialami oleh remaja. Kurangnya perhatian dan kasih sayang inilah yang menyebabkan putusnya komunikasi antara mereka dan memperburuk hubungan antara orang tua dengan anak. Selain itu, pemahaman orang tua yang kurang mengenai topik seputar seksual merupakan salah satu faktor 
mengapa orang tua tidak memberikan informasi tentang seks kepada remaja.

d. Dukungan Teman Sebaya

Distribusi Frekuensi Dukungan Teman Sebaya

\begin{tabular}{ccc}
\hline $\begin{array}{c}\text { Dukungan Teman } \\
\text { Sebaya }\end{array}$ & $\boldsymbol{f}$ & $\boldsymbol{\%}$ \\
\hline Tidak Mendukung & 40 & 44,0 \\
Mendukung & 51 & 56,0 \\
\hline Jumlah & $\mathbf{9 1}$ & $\mathbf{1 0 0}$ \\
\hline
\end{tabular}

Pada tabel dapat dilihat bahwa 51 $(56,0 \%)$ teman sebaya mendukung tentang perilaku seksual.

Teman sebaya diartikan sebagai kawan, sahabat atau orang yang samasama barkerja atau berbuat. Santrock (2011) mengatakan bahwa kawan-kawan sebaya adalah anak-anak atau remaja yang memiliki usia atau tingkat kematangan yang kurang lebih sama. Pengaruh teman sebaya sangat kuat sehingga munculnya penyimpangan prilaku seksual dikaitkan dengan norma kelompok sebaya

(Kusmiran, 2011).

Hasil penelitian ini berbeda dengan penelitian yang dilakukan oleh Mesra (2014) tentang pengaruh teman sebaya terhadap perilaku seksual remaja di SMA swasta Tangerang. Hasil penelitian ditemukan $10 \%$ peran teman sebaya negatif. Hasil penelitian ini juga berbeda dengan penelitian yang dilakukan oleh Istawati (2017) tentang hubungan keterpaparan media massa, peran teman sebaya terhadap tindakan seksual di SMA An-Naas. Hasil penelitian ditemukan $39,1 \%$ peran teman sebaya negatif.

Pengaruh teman sebaya dapat memberikan dampak perubahan perilaku pada remaja. Teman sebaya sendiri merupakan teman atau sahabat yang ikatan pertemanannya lebih erat dengan remaja, remaja sendiri sangat membutuhkan teman untuk dapat mencurahkan semua isi hatinya, dan pada saat ini teman sebaya berperan penting. Teman dapat memberikan pendapat, solusi dan saran. Biasanya pendapat, solusi maupun saran dari teman mudah diterima remaja daripada saran atau anjuran dari orang tua meskipun solusi tersebut belum diketahui kebenarannya terutama tentang seksual. Teman sebaya akan menjadi faktor yang berpengaruh terhadap perilaku seksual, karena teman sebaya lebih terbuka dalam memberikan informasi tentang seksual dari pada dengan orang tua maupun keluarga.

\section{Analisis Bivariat}

a. Hubungan Media Massa Dengan

Perilaku Seksual Pada Remaja 
Hubungan Media Massa Dengan Seksual Pada Remaja

\begin{tabular}{|c|c|c|c|c|c|c|c|c|}
\hline \multirow{3}{*}{$\begin{array}{l}\text { Media } \\
\text { Massa }\end{array}$} & \multicolumn{4}{|c|}{ Perilaku Seksual } & & & \multirow{3}{*}{$\begin{array}{c}p \\
\text { value }\end{array}$} & \multirow{3}{*}{ OR } \\
\hline & \multicolumn{2}{|c|}{ Beresilo } & \multicolumn{2}{|c|}{$\begin{array}{c}\text { Tidak } \\
\text { Beresilko }\end{array}$} & \multicolumn{2}{|c|}{ Total } & & \\
\hline & $\mathbf{n}$ & $\%$ & $\mathbf{n}$ & $\%$ & $\mathbf{n}$ & $\%$ & & \\
\hline Terpapar & 13 & 27,7 & 34 & 72,3 & 47 & 100 & & \\
\hline $\begin{array}{l}\text { Kurang } \\
\text { Terpapar }\end{array}$ & 2 & 4,5 & 42 & 95,5 & 44 & 100 & 0,007 & 8 \\
\hline Jumlah & 15 & 16,5 & 76 & 83,5 & 91 & 100 & & \\
\hline
\end{tabular}

\section{Perilaku}

Pada tabel diatas dapat dilihat bahwa hasil uji statistik dengan memakai rumus ChiSquare didapat $p$ value $=0,007(\mathrm{p}<$ $0,05)$ artinya ada hubungan media massa dengan perilaku seksual pada remaja. Dari analisis diperoleh nilai OR 8 , artinya responden yang terpapar terhadap media massa mempunyai peluang 8 kali memiliki perilaku seksual beresiko dibanding responden yang kurang terpapar terhadap media massa.

Adanya media massa masyarakat dapat dengan mudahnya mendapatkan informasi dan hiburan, namun dibalik itu media massa juga memiliki dampak negatif bagi masyarakat terutama remaja yang belum bisa dengan bijaksana memilah mana informasi atau hiburan yang benar dimana hal ini dapat mempengaruhi pembentukan dan perkembangan perilaku remaja. Dampak negatif dari media terutama pornografi merupakan hal yang serius untuk ditangani. Makin meningkatnya jumlah remaja yang mengakses informasi mengenai pornografi merupakan suatu masalah besar yang dapat berkontribusi terhadap meningkatnya jumlah remaja yang berperilaku seksual aktif (Nurhawa, 2016).

Sejalan dengan penelitian yang dilakukan oleh Babalola (2018) pada remaja di Nigeria, menemukan bahwa media massa berpengaruh sifnifikan terhadap perilaku seksual pada remaja $(\mathrm{p}=$ 0,001). Hasil penelitian ini juga sejalan dengan penelitian yang dilakukan oleh Yutifa (2015) tentang hubungan paparan pornografi melalui elektronik terhadap perilaku seksual remaja di 6 SMA/Sederajat di Pekanbaru. Hasil penelitian ditemukan adanya hubungan paparan pornografi melalui elektronik terhadap perilaku seksual remaja $(\mathrm{p}=0,000)$.

Media massa tidak dapat dikesampingkan dalam perannya menyampaikan informasi kepada masyarakat luas dan masih dianggap efektif untuk menyampaikan informasi terkait kesehatan reproduksi. Seiring dengan perkembangan zaman penggunaan handphone sebagai sumber informasi yang dapat diperoleh dengan mudah dan murah dan mudahnya para remaja mendapatkan dan menyewa VCD porno serta mengakses situs porno melalui internet serta penjualan buku porno/ majalah porno yang bebas dan televisi juga termasuk sumber yang paling mudah untuk ditonton oleh remaja dimana saat ini banyak sinetron atau film yang ada ditelevisi memperlihatkan dan mengarahkan para remaja ke arah yang 
tidak baik dalam segi perilaku seks. Selain itu, adanya remaja yang kurang terpapar dengan media massa tetapi masih memiliki perilaku seksual yang beresiko. Hal ini disebabkan oleh kurangnya pengawasan dan kontrol dari orang tua terhadap perilaku remaja, dimana banyak masih adanya dari remaja yang tidak tinggal bersama orang tuanya. Kurangnya pengawasan dari orangtua mengakibatkan remaja lebih rentan terhadap perilaku-perilaku yang negatif.

\section{b. Hubungan Pola Asuh Orang Tua}

Dengan Perilaku Seksual Pada Remaja

\section{Hubungan Pola Asuh Orang Tua}

\section{Dengan}

\section{Perilaku Seksual Pada Remaja}

\begin{tabular}{|c|c|c|c|c|c|c|c|}
\hline \multirow{3}{*}{$\begin{array}{l}\text { Pola Asuh } \\
\text { Orang Tua }\end{array}$} & \multicolumn{4}{|c|}{ Perilaku Seksual } & \multirow{2}{*}{\multicolumn{2}{|c|}{ Total }} & \multirow{3}{*}{$\begin{array}{c}p \\
\text { value }\end{array}$} \\
\hline & \multicolumn{2}{|c|}{ Beresiko } & \multicolumn{2}{|c|}{$\begin{array}{c}\text { Tidak } \\
\text { Beresiko }\end{array}$} & & & \\
\hline & $\mathbf{n}$ & $\%$ & $\mathbf{n}$ & $\%$ & $\mathbf{n}$ & $\%$ & \\
\hline Pernisif & 5 & 41,7 & 7 & 58,3 & 12 & 100 & \\
\hline Otoriter & 7 & 23,3 & 23 & 76,7 & 30 & 100 & 0,006 \\
\hline Demokratis & 3 & 6,1 & 46 & 93,9 & 49 & 100 & \\
\hline Jumlah & 15 & 16,5 & 76 & 83,5 & 91 & 100 & \\
\hline
\end{tabular}

Tabel diatas dapat dilihat bahwa hasil uji statistik dengan memakai rumus ChiSquare didapat $p$ value $=0,006(\mathrm{p}<$ $0,05)$ artinya ada hubungan pola asuh orang tua dengan perilaku seksual pada remaja.

Masalah seks pada remaja sering kali mencemaskan para orang tua juga pendidik, pejabat, pemerintah, para ahli, dan sebagainya. Perkawinan pada usia awal remaja pun pada akhirnya menjadi solusi akibat dari perilaku seksual yang pada akhirnya menimbulkan masalah yang tidak kalah peliknya. Dalam situasi apapun tingkah laku sesual pada remaja tidak menguntungkan. Padahal remaja adalah peralihan menuju kedewasaan, dimana mereka seyogyanya mulai mempersiapkan diri menuju kehidupan dewasa, termasuk dalam aspek seksualnya. Dengan demikian memang dibutuhkan sikap yang sangat bijaksana dari para orang tua, pendidik, dan masyarakat pada umumnya serta tentunya dari diri para remaja itu sendiri, agar mereka dapat melewati masa transisi itu dengan selamat. Adapun yang dimaksud perilaku seksual adalah segala tingkah laku yang didorong oleh hasrat seksual baik dengan lawan jenisnya maupun dengan sesama jenisnya. Bentukbentuk tingkah laku ini bisa bermacammacam, mulai dari perasaan tertarik, sampai tingkah laku berkencan, bercumbu, dan bersenggama. Objek seksualnya bisa berupa orang lain, orang dalam khayalan atau diri sendiri (Sarwono, 2016).

Hasil penelitian ini sejalan dengan penelitian yang dilakukan oleh Aguma (2014) tentang hubungan pola asuh orang tua terhadap perilaku seksual remaja di SMA Tri Bhakti Pekanbaru. Hasil penelitian ditemukan adanya hubungan pola asuh orang tua terhadap perilaku seksual remaja $(\mathrm{p}=0,001)$. Hasil penelitian ini juga sejalan dengan penelitian yang dilakukan oleh Hidayah (2013) tentang 
hubungan antara pola asuh orang tua dengan perilaku seksual pranikah pada remaja di SMK Batik 1 Surakarta. Hasil penelitian ditemukan adanya hubungan antara pola asuh orang tua dengan perilaku seksual pranikah pada remaja $(\mathrm{p}=0,000)$.

Ketidaktahuan orang tua tentang seks membuat orang tua mentabukan pembicaraan mengenai seks dengan remaja serta komunikasi yang tidak terbuka dengan remaja tentang seks, sehingga cenderung membuat jarak dengan anaknya. Dalam penelitian ini perilaku seksual yang berisiko banyak terdapat pada pola asuh orang tua yang menerapkan tipe pola asuh permisif dan otoriter. Hal ini mempunyai pengaruh terhadap perilaku seksual remaja. Orang tua seharusnya memberikan perhatian dan pengertian terhadap anaknya. Orang tua harus memberikan pengontrolan terhadap perilaku yang dilakukan pada anak atau remaja dan memberitahu batas-batas mana yang boleh dan tidak boleh dilakukan. Selain itu, pola asuh yang kurang beresiko juga disebabkan oleh masih kurangnya kesadaran remaja terhadap perilaku seksual dan adanya pengaruh dari media elektronik seperti mudahnya mengakses hal-hal yang berbau pornografi di internet serta adanya pengaruh dari teman-teman sebaya.

\section{c. Hubungan Dukungan Teman Sebaya}

Dengan Perilaku Seksual Pada Remaja

\section{Hubungan Dukungan Teman Sebaya}

Tabel diatas dapat dilihat bahwa hasil

Dengan Perilaku Seksual Pada Remaja

\begin{tabular}{|c|c|c|c|c|c|c|c|c|}
\hline \multirow{3}{*}{$\begin{array}{c}\text { Dukungan } \\
\text { Sebaya }\end{array}$} & \multicolumn{4}{|c|}{ Perilaku Seksual } & & & \multirow{3}{*}{$\begin{array}{c}p \\
\text { value }\end{array}$} & \multirow{3}{*}{ OR } \\
\hline & \multicolumn{2}{|c|}{ Beresiko } & \multicolumn{2}{|c|}{$\begin{array}{c}\text { Tidak } \\
\text { Beresiko }\end{array}$} & \multicolumn{2}{|c|}{ Total } & & \\
\hline & $\mathbf{n}$ & $\%$ & $\mathbf{n}$ & $\%$ & $\mathbf{n}$ & $\%$ & & \\
\hline Tidak & 11 & 27,5 & 29 & 72,5 & 40 & 100 & & \\
\hline Mendukung & & & & & & & 0,026 & 4 \\
\hline Mendukung & 4 & 7,8 & 47 & 92,2 & 51 & 100 & & \\
\hline Jumlah & 15 & 16,5 & 76 & 83,5 & 91 & 100 & & \\
\hline $\mathrm{uji}$ & & & & & $m$ & & amus & \\
\hline
\end{tabular}

ChiSquare didapat $p$ value $=0,026(\mathrm{p}<$ $0,05)$ artinya ada hubungan dukungan teman sebaya dengan perilaku seksual pada remaja. Dari analisis diperoleh nilai OR 4, artinya responden yang tidak mendapat dukungan dari teman sebaya mempunyai peluang 4 kali memiliki perilaku seksual beresiko dibanding responden yang mendapat dukungan dari teman sebaya.

Teman sebaya memiliki peran penting dalam kehidupan sosial dan perkembangan remaja. Informasi mengenai kesehatan reproduksi yang diperoleh melalui teman sebaya (peer) dapat mendorong remaja memiliki pengetahuan yang lebih baik. Remaja yang memiliki teman pernah melakukan hubungan seks pranikah lebih besar kemungkinan untuk ikut melakukan perilaku seks berisiko. Peran teman sebaya pada remaja laki-laki lebih besar dibandingkan dengan remaja perempuan, hal ini dimungkinkan karena perbedaan norma -norma sosial pada remaja laki-laki dan perempuan (Suparmi, 2012).

Hasil penelitian ini sejalan dengan penelitian yang dilakukan oleh Mesra (2014) tentang pengaruh teman sebaya 
terhadap perilaku seksual remaja di SMA swasta Tangerang. Hasil penelitian ditemukan adanya hubungan teman sebaya terhadap perilaku seksual remaja $(\mathrm{p}=$ 0,000). Hasil penelitian ini juga sejalan dengan penelitian yang dilakukan oleh Oktaviana (2015) tentang hubungan antara kelompok teman sebaya dengan perilaku seksual pranikah pada remaja di Kelurahan " $\mathrm{X}$ ” Palembang. Hasil penelitian ditemukan adanya hubungan kelompok teman sebaya dengan perilaku seksual pranikah pada remaja $(p=0,000)$.

Teman sebaya dapat memberitahukan tentang hal-hal seksual yang didapatkannya dari pengalamannya ataupun dari media internet yang kemudian ia beritahukan dengan temantemannya serta bujukan dan ajakan dari teman sebaya untuk melakukan perilaku seksual, sehingga sebagian besar dari informasi tersebut dapat mempengaruhi perilaku seksual mereka. Hal ini perlunya pengawasan orang tua dalam mengarahkan remaja dan menjalin komunikasi yang harmonis dan menciptakan keterbukaan terhadap masalah dan pembicaraan tentang seksualitas. Namun, hasil penelitian juga ditemukan teman sebaya yang tidak mendukung tetapi perilaku seksual remaja beresiko. Hal ini disebabkan oleh remaja lebih cenderung untuk tidak menceritakan hal-hal yang bersifat pribadi pada teman sebaya dan mereka mencari informasi lebih banyak melalui internet.

\section{KESIMPULAN DAN SARAN}

Berdasarkan penelitian yang telah dilakukan peneliti mendapatkan kesimpulan adalah :

1. Terdapat hubungan media massa dengan perilaku seksual pada remaja.

2. Terdapat hubungan pola asuh orang tua dengan perilaku seksual pada remaja.

3. Terdapat hubungan dukungan teman sebaya dengan perilaku seksual pada remaja.

Diharapkan kepada guru di SMK Negeri 2 Bukittinggi dalam memberikan informasi tentang pendidikan seksual melalui media seperti menggunakan aksesakses yang lebih bermanfaat dalam kegiatan proses belajar, kegiatan ekstrakurikuler seperti PMR (Palang Merah Remaja), UKS (Usaha Kesehatan Sekolah) dengan tenaga kesehatan dari puskesmas dan Dinas Kesehatan serta kegiatan-kegiatan keagamaan lainnya. Bagi institusi kesehatan diharapkan juga sosialisasi para tenaga kesehatan atau pakar dalam bidang kesehatan reproduksi untuk dapat menambah ilmu pengetahuan dan cara hidup yang sehat agar terhindar dari penyakit menular seksual dan terhindar dari 
perilaku seksual beresiko serta memberikan informasi kepada orang tua agar berkomunikasi dengan baik kepada anak tentang seksual.

\section{UCAPAN TERIMA KASIH}

Peneliti mengucapkan terima kasih kepada semua pihak yang telah membantu penelitian ini.

\section{DAFTAR PUSTAKA}

Aguma, R.P. 2014. Hubungan Pola Asuh Orangtua Terhadap Perilaku Seksual Remaja di SMA Tri Bhakti Pekanbaru. Jurnal Keperawatan Universitas Riau

Andika, A. 2010. Bicara Seks Bersama Anak, Jakarta : Pustaka Anggrek.

Andriani, H. 2016. Hubungan Pengetahuan, Akses Media Informasi dan Peran Keluarga Terhadap Perilaku Seksual pada Siswa SMK Negeri 1 Kendari. Jurnal Fakultas Kesehatan Masyarakat Universitas Halu Oleo Babalola. L. 2018. Media Use and Sexual Behavior: A Study of Adolescents in Selected Secondary Schools in Ede, Osun State. Arts Social Sci J, an open access journal Volume 9 • Issue 1
Biro Pusat Statistik Kota Padang, 2018 BKKBN, 2011. Policy brief pusat penelitian dan pengembangan Kependudukan. Seri I No.6/PusduBKKBN/. Diakses tanggal 23 september 2019

Chaves, L.E, et all. 2007. Impact of the Media on Adolescent Sexual Attitudes and Behaviors in American. Pediatrics Vol. 116 No. 1

Depkes RI. 2018. Kesehatan Reproduksi. Jakarta

Hidayah, N.F.N. 2013. Hubungan Antara Pola Asuh Orang Tua Dengan Perilaku Seksual Pranikah Pada Remaja di SMK Batik 1 Surakarta. GASTER Vol. 10 No. 2

Kusmiran, E, 2011. Kesehatan Reproduksi Remaja dan Wanita. Jakarta : Salemba Medika

Lutfianawati, D. 2014. Hubungan Peran Orang Tua Dengan Sikap Remaja Tentang Seks Bebas di MAN Wlingi Kabupaten Blitar. Jurnal Ners dan Kebidanan, Volume 1, Nomor 2, Juli 2014, hlm. 103-109. STIKes Patria Husada Blitar

Mesra, E. 2014. Pengaruh Teman Sebaya Terhadap Perilaku Seksual Remaja di SMA Swasta Tangerang. Jurnal Ilmiah Bidan, Vol. I, No. 2, 2016 
Nurhawa, 2016. Studi Komparatif Perilaku Seksual Pada Siswa MAN 1 Kendari dan Siswa SMKN 1 Kendari. Jurnal Ilmiah Mahasiswa Kesehatan Masyarakat Vol. 2/No.5/ Januari 2017. Fakultas Kesehatan Masyarakat Universitas Halu Oleo Oktaviana, R. 2015. Hubungan Antara Kelompok Teman Sebaya Dengan Perilaku Seksual Pranikah Pada Remaja di Kelurahan " $X$ " Palembang. Jurnal Ilmiah PSYCHE Vol.9 No.1 Juli 2015: 11-26

Pramita, D. 2011. Hubungan Komunikasi Orang Tua dan Anak Tentang Seks Dengan Perilaku Seks pada Remaja di SMA N 1 Seyegan Sleman Yogyakarta. Naskah Publikasi. STIKes ‘Aisyiyah Yogyakarta

Istawati, R. 2017. Hubungan Keterpaparan Media Massa, Peran Teman Sebaya Terhadap Tindakan Seksual di SMA An-Naas. Journal Endurance 2(2) June 2017 (124-131)

Sarwono. 2016. Psikologi Remaja. Jakarta : PT. Rajawali Pers

Santrock, J. W. 2011. Masa Perkembangan Anak (Edisi 11Buku 2). Jakarta: Salemba Humanika.

Suparmi. 2012. Peran Teman Sebaya terhadap Perilaku Seksual Pranikah pada Remaja Laki-Laki dan Perempuan di Indonesia. Buletin Penelitian Kesehatan, Vol. 44, No. 2, Juni $2016: 139$ - 146

Trisnawati, Y. 2010. Faktor-Faktor yang Berhubungan Dengan Perilaku Seksual Pada Remaja SMA di Purwokerto. Jurnal Ilmiah Kebidanan, Vol. 1 No. 1 Edisi Desember 2010

Ungsianik, T. 2016. Hubungan Pola Asuh Orangtua Dengan Perilaku Seksual Berisiko Pada Remaja, Khususnya Remaja Anak Jalanan di Kota Depok. Jurnal Keperawatan Indonesia, Volume 20 No.3, November 2017, hal 185-194

Yusuf, S. 2011. Psikologi Perkembangan. Bandung: PT Remaja Rosdakarya. Yutifa, H. 2015. Hubungan Paparan Pornografi Melalui Elektronik Terhadap Perilaku Seksual Remaja di $6 \mathrm{SMA} /$ Sederajat di Pekanbaru. JOM Vol 2 No 2, Oktober 2015 